\title{
Pending legislation would affect animal research in US
}

Several bills now pending before Congress would potentially have great impact on the conduct of biomedical research. Two of these bills would make it easier for law enforcement agencies to arrest and prosecute individuals who damage or disrupt animal research, and the other two would prevent Class B dealers from providing random source dogs and cats for use in research.

\section{Animal Enterprise Terrorism Act}

S. 1926, introduced by Senator James Inhofe (R-OK) on 27 October 2005, and the related H.R. 4239, introduced by Representative Thomas Petri (R-WI) on 4 November 2005, both known as the 'Animal Enterprise Terrorism Act,' will “provide the Department of Justice the necessary authority to apprehend, prosecute, and convict individuals committing animal enterprise terror ${ }^{1,2}$."

The Animal Enterprise Terrorism Act rewrites federal criminal code to prohibit anyone from traveling in interstate or foreign commerce or using the mail system to damage or disrupt an animal enterprise (e.g., animal breeders, research institutes, zoos, animal shelters, etc.). The Act would make it an offense to intentionally damage property, cause or threaten to cause serious bodily harm, or conspire or attempt to do so.

The bill outlines penalties for economic damage, bodily harm, and death resulting from Animal Enterprise Terrorism and authorizes restitution "(1) for the reasonable cost of repeating any experimentation that was interrupted or invalidated as a result of such offense; (2) the loss of food production or farm income reasonably attributable to such offense; and (3) for any other economic damage, including any losses or costs caused by economic disruption, resulting from such offense."

Pet Safety and Protection Act of 2005 The Pet Safety and Protection Act of 2005 was introduced on 17 February 2005 by Senator
Daniel Akaka (D-HI) as S. 451 (ref. 3) and on 27 April 2006 by Representative Philip English (R-PA) as H.R. 5229 (ref. 4). The intent of the bills is to "amend the Animal Welfare Act (AWA) to ensure that all dogs and cats used by research facilities are obtained legally."

This Act would bar the sales of random source animals of Class B dealers to research facilities. It would amend the AWA list of permissible sources of dogs and cats used by research facilities to include dogs and cats obtained from: a licensed dealer that bred and raised that animal; a publicly owned and operated pound or shelter registered with the USDA, a person who bred and raised the dog or cat and owned it for at least one year, and a research facility licensed by the USDA.

1. H.R.4239. Animal Enterprise Terrorism Act http://www.govtrack.us/congress/billtext. xpd?bill=h109-4239.

2. S.1926. Animal Enterprise Terrorism Act. http://www.govtrack.us/congress/billtext. xpd?bill=s109-1926.

3. S. 451. Pet Safety and Protection Act of 2005. http://www.govtrack.us/congress/billtext. xpd?bill=s109-451.

4. H.R. 5229. Pet Safety and Protection Act of 2005. http://www.govtrack.us/congress/ billtext.xpd?bill=h109-5229.

\section{EU to rework animal welfare rules}

The Commission of the European Union (EU) is preparing to revise Directive 86/609/ EEC, which has regulated the use of animals in experimental and other scientific purposes within the EU since 1986. As such, they have asked the EU public and scientists to provide their views on the regulation of laboratory animal research ${ }^{1}$.

The 1986 Directive 86/609/EEC on the protection of animals used for research and other scientific purposes was intended to improve laboratory animal welfare by setting standards for housing and care and for training animal care personnel and investigators. To reduce the numbers of animals used for experiments, the Directive prohibited the use of animals in experiments for which alternative methods exist.

The recent public consultation on the revision of Directive 86/609/EEC, which closed on 18 August 2006, aimed to:

- "Provide the Commission with views of the public on their attitudes on the use of animals in experiments and ways to improve their welfare; and
- "Comment on the preliminary findings of the impact assessment for the revision of the existing legislation for the protection of animals used in experiments ${ }^{1}$."

The Commission issued two questionnaires for this consultation. The first, available in 20 languages, allowed interested EU citizens to express their views about animal welfare. The second questionnaire was developed for use by experts in the field of laboratory animal science with detailed technical questions in English. To ensure transparency, the Council will publish on its website the answers it receives.

The responses will help the Commission to draft a proposal, which will be forwarded to the European Parliament and the Council. The legislative process for adoption of a new Directive may take at least two years.

1. Increasing the welfare of animals used in experiments Public consultation on the revision of Directive $86 / 609 / \mathrm{EEC}$ on the protection of animals used for experimental and other scientific purposes. (22 June 2006). http:// ec.europa.eu/environment/chemicals/lab_ animals/ia_info_en.htm\#5. 